AUTHORS:

V. Cliff Moran

John H. Hoffmann

Helmuth G. Zimmermann ${ }^{2}$

\section{AFFILIATIONS:}

'Department of Biological Sciences, University of Cape

Town, Cape Town, South Africa

${ }^{2}$ Agricultural Research

Council - Plant Protection

Research Institute, Pretoria,

South Africa

\section{CORRESPONDENCE TO:} John Hoffmann

\section{EMAIL:}

john.hoffmann@uct.ac.za

\section{POSTAL ADDRESS:}

Department of Biological Sciences, University of Cape

Town, Private Bag, Rondebosch 7701, South Africa

\section{KEYWORDS:}

\section{weeds; conservation;} environmental management; risks; safety procedures; costs and benefits

\section{HOW TO CITE:}

Moran VC, Hoffmann JH, Zimmermann HG. 100 years of biological control of invasive alien plants in South Africa: History, practice and achievements. S Afr J Sci. 2013;109(9/10), Art. \#a0022, 6 pages. http://dx.doi. org/10.1590/sajs.2013/a0022

(C) 2013. The Authors. Published under a Creative Commons Attribution Licence.

\title{
100 years of biological control of invasive alien plants in South Africa: History, practice and achievements
}

\begin{abstract}
How it all started
On 26 June 1906, the fourth Parliamentary Select Committee on Agricultural Cooperation met in Cape Town to debate the apparently intractable scourge to agriculture, and the wider community, of dense infestations of sweet prickly pear (Opuntia ficus-indica) in the Eastern Cape and Karoo. ${ }^{1,2}$ Originating from Central America, this plant had been in South Africa since at least the 1750s, and by the 1890s had invaded an estimated 314000 ha, which increased to about 1 million ha by the 1950s. ${ }^{1}$ Dr G.H. Maasdorp, a member of the Legislative Assembly of the Cape and a medical practitioner in Graaff-Reinet, ${ }^{3}$ which was literally in the thick of the prickly pear problem at the time, presented his perceptive views to the Committee $e^{1,4}$ :
\end{abstract}

\begin{abstract}
...I think we should find out what are the conditions in those countries in which [the prickly pear] is indigenous whether it is in the nature of a pest there or not...it may possibly be that in those countries this plant has some natural enemy for keeping [it] within bounds. ... and whether it would not be possible to transport that natural enemy to this country. It is a difficulty I think with all imported plants...that where they do not meet their natural enemies they...become a pest.
\end{abstract}

Dr Maasdorp had succinctly explained the fundamental principles of weed biological control (WBC) (i.e. the use of imported plant-feeding or plant-damaging organisms, 'natural enemies', also called WBC agents, to suppress problematic plants). However, a crucial point had apparently been missed: WBC is effective only because the imported natural enemies themselves are devoid of their own natural enemies and thus have the potential for rapid population expansion on the targeted weeds in the country of introduction. In any event, a quarter of a century of political prevarication ensued because sweet prickly pear has several beneficial attributes (it bears copious quantities of edible fruits, and spineless varieties had long been cultivated as a drought-fodder crop) and it was only in 1933 that permission was ultimately granted to release a biological control agent against sweet prickly pear in South Africa ${ }^{1,5}$ - the now-famous cactus moth, Cactoblastis cactorum.

Perhaps unbeknown to the Select Committee was the fact that, during the late 18th century, India had inadvertently illustrated the efficacy of WBC. In an attempt to obtain the commercially valuable dye-producing cochineal insect, Dactylopius coccus, entrepreneurs had erroneously imported another species, Dactylopius ceylonicus, from South America. This mistake resulted in the decimation of large areas of an extremely problematic cactus, called drooping prickly pear (Opuntia monacantha) between 1796 and 1809. Dactylopius ceylonicus was subsequently introduced into Ceylon (Sri Lanka) where it also successfully controlled the drooping prickly pear. ${ }^{6}$

Seemingly, news of this 'Deadly Indian Cochineal' reached South Africa only in $1910^{1,7}$ and, in 1913, in South Africa's first venture in WBC, $D$. ceylonicus was imported and released as a biological control agent against drooping prickly pear, which, at the time, was highly invasive along the coast from the Western Cape to Durban. Lounsbury ${ }^{7}$ recorded that

[in] about September, 1913, ...some material of the Indian species [of cochineal was placed] in a clump of Monacantha [sic] prickly pear growing [near] Pietermaritzburg. ...The insect soon spread...and in the following winter only the trunk-like stems were standing. The joints had blighted and fallen down...in masses...presenting a most miserable spectacle.

The cochineal insects were then more widely distributed to other parts of the country, and within a few years drooping prickly pear had been completely controlled and has remained so ever since. Unfortunately this extraordinary precedent carries the misleading connotation that WBC is quick and easy, when in fact, in the majority of cases, WBC requires protracted research, success is not assured, and the benefits are often manifested only after many years have elapsed.

It is also tempting to conclude from these early records that South Africans were pioneers in WBC. That is not the case, but they were not far behind. The first research-based WBC project commenced in 1902 in Hawaii where several insect species were released as biological control agents against lantana, Lantana camara, but with little success. ${ }^{8}$ In 1903, the Australians deliberately imported cochineal insects from India against drooping prickly pear ${ }^{6}$ (and they provided the initial culture of $D$. ceylonicus that was imported into South Africa in $1913^{7}$ ). The 1903 attempt in Australia failed but further releases in 1914 were a resounding success. This success motivated the Australians to mount, in 1920, what was to become recognised as the most extensive and accomplished of any WBC project in the world: that against a devastatingly problematic cactus, the 'pest [prickly] pear', Opuntia stricta. ${ }^{9,10}$

The purpose of this synoptic account is to provide a perspective on the problem of invasive alien plants in South Africa, to elaborate on the basic principles and procedures in WBC, to summarise our achievements, and to commemorate some attributes that have incrementally gained the country a reputation for innovation and success in this field of endeavour. 


\section{Invasive alien plants in South Africa: A WBC perspective}

In common with other countries that have a long colonial history, ${ }^{11}$ several thousand species of alien plants have been introduced into South Africa. Many of these have become naturalised and, some, following a long 'lag' phase which may last many decades, suddenly increase in abundance and become invasive weeds. In this country, introductions which started in the 1600 s and peaked in the $1800 \mathrm{~s}^{12}$ have resulted in about 200 species now being listed as damaging in an agricultural or pastoral context or in natural and conserved ecosystems. ${ }^{13-16}$ Many are also responsible for decreasing water run-off and groundwater reserves at rates that are far in excess of water usage by the natural vegetation types, which is especially problematic in this water-scarce country. ${ }^{17}$

South Africa is recognised as having severe difficulties with the sheer numbers of species of invasive plants. For example, Richardson and Rejmánek ${ }^{11}$, in a recent global review, listed 63, 90, 105 and 117 species of invasive trees in South America, North America, Australia and 'southern' (i.e. south of $20^{\circ} \mathrm{S}$ ) Africa, respectively. Henderson ${ }^{18}$ lists 93 species of invasive trees in South Africa. In comparison to other continental regions, and expressed in relation to total land surface areas, South Africa has several times more invasive alien species of trees per square kilometre than anywhere else. While this means little in terms of measures of distributions, density or impact, South Africa, in respect of damaging invasions by alien plants, is clearly an unfortunate outlier.

Taking an overall and approximate view of the most important of the declared weeds in South Africa, ${ }^{13-19}$ from the perspective of a WBC practitioner thinking about the impact and management of these invasive species, there are some generalities that become apparent.

Firstly, there are virtually no permanent open waters (lakes) in South Africa (the surface area of water is less than about $0.4 \%$ of the country's total area) yet a succession of floating alien weed species have imposed enormous damage and costs. Ironically, over recent decades, as WBC has significantly reduced the problem of floating weeds in South Africa, a suite of submerged aquatic weeds that have proved to be invasive elsewhere in the world have moved into the open water bodies, presenting the next major challenge for WBC in this country. ${ }^{20}$

Secondly, perhaps even more badly affected are our riparian habitats which have been transformed and degraded by alien tree species such as black wattle (Acacia mearnsii) and gums (Eucalyptus spp.). 'Few if any river systems [in South Africa] have not been extensively invaded'13.

Thirdly, terrestrial ecosystems in higher rainfall regions harbour the majority of alien plant species. The Cape Floristic Region is dominated by Australian Acacia and Hakea species and, increasingly, by pines (Pinus spp.). ${ }^{16}$ The subtropical eastern regions have the dubious distinction of hosting the most varied assortment of invasive plant species, including many tree species and environmentally damaging shrubs such as triffid weed (Chromolaena odorata) and the many very closely related Lantana camara taxa. As with the water weeds, when WBC gains the ascendancy against particular invasive species in terrestrial habitats, 'replacement' species sometimes proliferate, creating further challenges and a need for intervention.

Lastly, In South Africa's drier regions, the alluvial plains and the ephemeral watercourses are severely impacted by Prosopis species (mesquite) hybrids, a limited number of other woody invaders, and by cacti and shrubs. ${ }^{13}$

This broad perspective is anything but static. Potentially devastating invasive plants such as pompom weed, Campuloclinium macrocephalum, and the noxious parthenium weed Parthenium hysterophorus, also known as 'famine weed' in South Africa, are rapidly increasing in importance, and there are many other incipient or emerging weed species in this country, ${ }^{21}$ some of which have already proved to be very damaging elsewhere in the world.

These matters have long had the attention of various government departments and, crucially, since 1995, the Working for Water Programme (previously in the Department of Water Affairs, now in the Department of Environmental Affairs) has expended more than R3 billion on mechanical and chemical control operations. At best, this investment has just managed to retard, rather than reverse, the invasions. There is now wide recognition that more needs to be invested in research and implementation of WBC if the situation is to be at least stabilised, or improved. ${ }^{22,23}$

\section{The practice of weed biological control}

Conceptually, the practice of WBC is deceptively straightforward but, as is often the case, the devil is in the detail. In fact, there are considerable research and practical challenges (Table 1). Besides the accurate identification of the target weeds and the collection and importation of suitable candidate agents into quarantine, the main issue is to determine their safety for release and their potential to control the target weed. These findings form the basis of risk assessments for scrutiny by the relevant regulatory authorities who ultimately decide which agents may be released.

The determination of the host specificity of candidate agents has been paramount since the inception of concerted research into WBC at the beginning of the 1900s. ${ }^{24}$ Single-host or multiple-host tests reveal the host-plant, feeding and egg-laying preferences of prospective agents to address the question that is always asked: 'What if the agent eliminates its intended host plant and then starts to damage beneficial or native plants?' Within all the major groups of plant-feeding insects, many species are monophagous (i.e. they are host specific and can survive on only one species of host plant) or are oligophagous and can survive only on a narrow range of closely related plant species. ${ }^{25}$ Monophages are obviously the agents of choice for WBC. In certain circumstances, however, oligophages, such as some cactus-feeding species, may also be suitable for release because they are associated with host plant species that have no close relatives in the region where their releases are planned. Candidate agents in these categories, particularly those that have been tested, released and proven safe elsewhere in the world, require relatively short periods of confirmatory testing. Many prospective agents require much more elaborate and protracted testing (sometimes for as long as 9 years ${ }^{26}$ ) because they have never been previously tested or because they are intended for use against target weeds that are taxonomically related to important crops or to native plants. Examples of these WBC agents include candidates tested in South Africa for use against bugweed, Solanum mauritianum, which is in the same family as some important crops including potatoes and tomatoes.

Records from South Africa indicate that the average duration of specificity testing before WBC agents were released is nearly 4 years per agent tested. ${ }^{26}$ Because of doubts about adequate specificity or because the agents did not seem to have the potential for sufficient impact on the target weed species, South African WBC research scientists have investigated and then rejected 64 species of candidate agents. ${ }^{27}$ None of the WBC agents released in South Africa over the last 100 years have had any untoward or damaging consequences for beneficial or native plant species. ${ }^{26,27}$

\section{What has been achieved?}

Since 1913, South African entomologists and plant pathologists have considered 270 taxonomic entities (species or biotypes) of organisms including insects (87\%), mites (2\%) and pathogens (11\%) that have the ability to feed and develop on, and thereby damage, their respective target weeds. ${ }^{27}$ Of these, 106 were tested and released and 75 have become established as biological control agents on 48 species of invasive alien plants $^{27}$ (Table $2^{1,28-31}$ ). Six of the early South African projects, against four species of cacti, lantana and St. John's wort (Hypericum perforatum), were projects based on research and precedents from other countries. Since the late 1960s, South Africa has mounted independent research projects in WBC (although continuing to cooperate closely with other leading nations in biological control, namely Australia, the USA, New Zealand and Canada), targeting many weed species that have not been tackled anywhere else in the world. In recent years South Africa has been able to reciprocate previous generosity and goodwill by providing Australia and New Zealand with agents that have been developed entirely in this country. 
Table 1: $\quad$ Sequential phases and processes involved in weed biological control (WBC) and associated challenges

\begin{tabular}{|c|c|c|}
\hline Main phases in WBC & Research procedures & Comments and challenges \\
\hline Determine identity of target weed species & $\begin{array}{l}\text { Undertake taxonomic, phylogenetic and molecular } \\
\text { genetic studies }\end{array}$ & $\begin{array}{l}\text { Accurate identity often very complicated } \\
\text { (cryptic species, varieties, hybrids, cultivars) }\end{array}$ \\
\hline Determine origin of target weed species & $\begin{array}{l}\text { Perform herbarium and literature searches; } \\
\text { explore area; search historical records }\end{array}$ & $\begin{array}{l}\text { Many failures in WBC relate to exploration in the } \\
\text { wrong region }\end{array}$ \\
\hline $\begin{array}{l}\text { Explore for suitable plant-feeding agents in area } \\
\text { of origin of target weed }\end{array}$ & $\begin{array}{l}\text { Identify candidate agents; explore indications of } \\
\text { host ranges; study biology of agents and of close } \\
\text { taxa elsewhere }\end{array}$ & $\begin{array}{l}\text { Foreign exploration expensive, difficult and } \\
\text { sometimes dangerous; expedite process through } \\
\text { formal involvement of local research institutions }\end{array}$ \\
\hline $\begin{array}{l}\text { Export candidate agents from country of origin } \\
\text { to country where releases are intended }\end{array}$ & $\begin{array}{l}\text { Determine optimal conditions for maintenance } \\
\text { and transportation }\end{array}$ & $\begin{array}{l}\text { Permits to export agents from foreign countries } \\
\text { sometimes impossible to obtain; quarantine facilities } \\
\text { are required to receive and rear agents }\end{array}$ \\
\hline $\begin{array}{l}\text { Perform studies to confirm that agents are } \\
\text { suitable and safe for release }\end{array}$ & $\begin{array}{l}\text { Determine host ranges (safety) of candidate } \\
\text { agents under quarantine conditions; assess } \\
\text { potential efficacy by type and extent of } \\
\text { damage caused }\end{array}$ & $\begin{array}{l}\text { Choose test plants, usually by taxonomic } \\
\text { relatedness to target weed, including native plants } \\
\text { and crops; climate-controlled, quarantine facilities } \\
\text { are specialised and very expensive }\end{array}$ \\
\hline Apply for permits to release agents & $\begin{array}{l}\text { Analyse research findings on host range and } \\
\text { potential efficacy of agents; prepare motivations } \\
\text { for release }\end{array}$ & $\begin{array}{l}\text { Research results subject to peer review; cultures of } \\
\text { agents that fail safety tests or may not be effective } \\
\text { are destroyed; final approval often protracted }\end{array}$ \\
\hline Mass rear approved agents & $\begin{array}{l}\text { Develop techniques to maintain large colonies } \\
\text { as a source of agents for field releases onto the } \\
\text { target weed }\end{array}$ & $\begin{array}{l}\text { Hygienic conditions required to avoid overcrowding } \\
\text { and disease; retain genetic integrity of agent cultures }\end{array}$ \\
\hline $\begin{array}{l}\text { Release approved agents onto the target weed } \\
\text { in the field }\end{array}$ & $\begin{array}{l}\text { Determine optimal release techniques to improve } \\
\text { chances of agent establishment }\end{array}$ & $\begin{array}{l}\text { Timing, condition of target plant, and number of } \\
\text { agent individuals released are important factors }\end{array}$ \\
\hline $\begin{array}{l}\text { Determine whether populations of agent have } \\
\text { established on target weed }\end{array}$ & $\begin{array}{l}\text { Monitor persistence and fluctuations in numbers, } \\
\text { as well as spread of agents on target host }\end{array}$ & $\begin{array}{l}\text { Several releases of agents at many sites may } \\
\text { be necessary }\end{array}$ \\
\hline Enhance distribution of agents in the field & $\begin{array}{l}\text { Determine where agent populations are thriving } \\
\text { and use for wider distribution }\end{array}$ & $\begin{array}{l}\text { Some agents are slow to disperse and require } \\
\text { repeated manual interventions (re-distribution) }\end{array}$ \\
\hline Assess direct impact of agents on target weed & $\begin{array}{l}\text { Quantify in detail the damage caused to different } \\
\text { parts of the plant }\end{array}$ & $\begin{array}{l}\text { Frequent monitoring of damage levels required over } \\
\text { several seasons }\end{array}$ \\
\hline $\begin{array}{l}\text { Evaluate effects of agents on weed } \\
\text { population dynamics }\end{array}$ & $\begin{array}{l}\text { Determine changes in density and dispersal } \\
\text { patterns of target weed before and after agents } \\
\text { have established }\end{array}$ & $\begin{array}{l}\text { Studies required over several decades on agent/plant } \\
\text { interactions, seed dynamics and plant ecology }\end{array}$ \\
\hline Integrate WBC with other control practices & $\begin{array}{l}\text { Determine optimal use of WBC as a supplement or } \\
\text { replacement for other control strategies }\end{array}$ & $\begin{array}{l}\text { In some cases WBC is exclusively employed, but } \\
\text { often WBC is used together with mechanical or } \\
\text { chemical control }\end{array}$ \\
\hline Perform cost: benefit analyses & $\begin{array}{l}\text { Determine long-term costs of research and } \\
\text { implementation of WBC; estimate benefits and } \\
\text { economic viability of WBC }\end{array}$ & $\begin{array}{l}\text { Compare costs and benefits with other forms of } \\
\text { weed suppression; consider risks and costs of not } \\
\text { using WBC }\end{array}$ \\
\hline
\end{tabular}


Table 2: Invasive alien plants (weeds) on which biological control agents (species or biotypes) have become established in South Africa over the last 100 years

\begin{tabular}{|c|c|c|c|c|c|c|c|c|c|c|c|c|c|c|c|c|c|c|}
\hline WEEDS (Total number of agent species established) & $1910 s$ & $1920 s$ & \multicolumn{2}{|c|}{$1930 s$} & \multicolumn{2}{|c|}{ 1940s } & $1950 s$ & \multicolumn{2}{|c|}{$1960 s$} & \multicolumn{2}{|c|}{ 1970s } & \multicolumn{2}{|c|}{$1980 s$} & \multicolumn{2}{|c|}{ 1990s } & \multicolumn{2}{|c|}{$2000 s$} & 2010 \\
\hline \multicolumn{19}{|l|}{ CACTI } \\
\hline \multicolumn{19}{|l|}{ Opuntia monacantha (2) } \\
\hline Opuntia ficus-indica (4) & & & * & * & * & * & & & & & & & & & & & & \\
\hline Opuntia aurantiaca (2) & & & & * & & & & & & & & & & & & & & \\
\hline Opuntia engelmanii (2) & & & & * & & & & & & & & & & & & & & \\
\hline \multicolumn{19}{|l|}{ Cylindropuntia imbricata (1) } \\
\hline Cylindropuntia fulgida v. fulgida (2) & & & & & & & & & & * & & & & & & & * & \\
\hline Cylindropuntia leptocaulis (1) & & & & & & & & & & & * & & & & & & & \\
\hline Opuntia stricta (2) & & & & & & & & & & & & * & & & * & & & \\
\hline Harrisia martinii (2) & & & & & & & & & & & & * & & * & & & & \\
\hline Cereus jamacaru/ hildmannianus (2) & & & & & & & & & & & & & & * & & & & \\
\hline Pereskia aculeata (1) & & & & & & & & & & & & & & * & * & & & \\
\hline Harrisia bonplandii (1) & & & & & & & & & & & & & & & & & * & \\
\hline AGENTS ESTABLISHED ON CACTUS WEEDS: DATES L & NKNOWI & & & & & & & & & & & & & & & & & \\
\hline Austrocylindropuntia subulata (1) & & & & & & & & & & $?$ & & & & & & & & \\
\hline Opuntia salmiana (1) & & & & & & & & & & $?$ & & & & & & & & \\
\hline Opuntia spinulifera (1) & & & & & & & & & & $?$ & & & & & & & & \\
\hline SHRUBS, HERBS AND CLIMBERS & & & & & & & & & & & & & & & & & & \\
\hline Lantana camara (17) & & & & & & & * & * & & * & * & * & & & * & * & * & \\
\hline Hypericum perforatum (2) & & & & & & & & * & * & * & & & & & & & & \\
\hline Solanum elaeagnifolium (3) & & & & & & & & & & & * & & & * & & & & \\
\hline Cirsium vulgare (1) & & & & & & & & & & & & * & * & & & & & \\
\hline Ageratina adenophora (2) & & & & & & & & & & & & * & * & & & & & \\
\hline Ageratina riparia (1) & & & & & & & & & & & & & * & & & & & \\
\hline Solanum sysimbriifolium (1) & & & & & & & & & & & & & & * & & & & \\
\hline Caesalpinia decapetala (1) & & & & & & & & & & & & & & & $\star$ & & & \\
\hline Dolichandra unguis-cati (3) & & & & & & & & & & & & & & & * & & * & \\
\hline Chromolaena odorata (2) & & & & & & & & & & & & & & & & * & & \\
\hline TREES & & & & & & & & & & & & & & & & & & \\
\hline Hakea sericea (5) & & & & & & & & & & * & * & $\star$ & & & & * & * & \\
\hline Sesbania punicea (3) & & & & & & & & & & * & & * & & & & & & \\
\hline Hakea gibbosa (2) & & & & & & & & & & & * & & & & & * & & \\
\hline Acacia longifolia (2) & & & & & & & & & & & & * & * & & & & & \\
\hline Acacia melanoxylon (1) & & & & & & & & & & & & & * & & & & & \\
\hline Acacia pycnantha (2) & & & & & & & & & & & & & * & * & & & * & \\
\hline Acacia saligna (2) & & & & & & & & & & & & & * & & & * & & \\
\hline Paraserianthes lophantha (1) & & & & & & & & & & & & & * & & & & & \\
\hline Prosopis hybrids (2) & & & & & & & & & & & & & * & * & & & & \\
\hline Acacia cyclops (2) & & & & & & & & & & & & & & * & & * & & \\
\hline Acacia mearnsii (2) & & & & & & & & & & & & & & * & $\star$ & * & & \\
\hline Acacia dealbata (1) & & & & & & & & & & & & & & * & $\star$ & * & * & \\
\hline Leptospermum laevigatum (2) & & & & & & & & & & & & & & * & * & & & \\
\hline Leucaena leucocephala (1) & & & & & & & & & & & & & & & * & & & \\
\hline Solanum mauritianum (2) & & & & & & & & & & & & & & & * & & * & \\
\hline Acacia decurrens (1) & & & & & & & & & & & & & & & & * & * & \\
\hline Acacia baileyana (1) & & & & & & & & & & & & & & & & & * & \\
\hline Acacia podalyriifolia (1) & & & & & & & & & & & & & & & & & * & \\
\hline WATER WEEDS & & & & & & & & & & & & & & & & & & \\
\hline Eichhornia crassipes (6) & & & & & & & & & & * & * & * & * & * & * & & & \\
\hline Salvinia molesta (2) & & & & & & & & & & & & & * & & & & & \\
\hline Pistia stratiotes (2) & & & & & & & & & & & & & * & & & & & \\
\hline Myriophyllum aquaticum (1) & & & & & & & & & & & & & & * & & & & \\
\hline Azolla filiculoides (1) & & & & & & & & & & & & & & & * & & & \\
\hline
\end{tabular}

Sources: The records are derived from three review volumes ${ }^{28-30}$ and from personal communications for more recent developments.

The weeds are grouped in categories ${ }^{18}$ and then listed chronologically, in 5-year intervals, by the date of the first release of an agent entity. ${ }^{27}$ First and subsequent releases of the same or of different agent entities are indicated by asterisks. Dark grey shading indicates that complete control of the weed has been achieved; medium grey shading that substantial control has been achieved; and light grey shading that control is trivial or not determined.

Note: In the case of L. camara, three agent species were released and established 'pre-1961': these releases are indicated by an asterisk in the late 1950s period. 
Following the release of a WBC agent, a period of several years may elapse before populations of the agents build up to levels where there is a noticeable impact on the distributions or densities of the target weeds. Of the weed species in South Africa on which agents have become successfully established, $23 \%$ have been completely controlled (i.e. no other control measures have been needed) and $38 \%$ are under substantial biological control (i.e. other control measures may be intermittently or routinely needed, but less effort or expenditure is required than would have been the case in the absence of the WBC agents; Table $2^{1,28-31}$ ). In most cases these benefits have been sustained for decades and will continue to accrue into the future.

It is clear from Table 2 that there has been a surge in activity (i.e. number of species targeted and WBC agents released) in recent years, but not enough time has yet elapsed for these WBC agents to have brought about a significant decrease in the abundance of the targeted weed populations. What cannot be determined from Table 2 is that there are at least 15 invasive alien plant species, including incipient or emerging weeds, that are currently the subject of active WBC research but which have not been listed because no agents have yet been released on them. ${ }^{27}$

\section{Some factors that have enhanced WBC endeavours in South Africa}

After 100 years of effort, it is instructive to record some of the reasons for the successes achieved and to consider the current vigour and prospects for expansion of the science of WBC in South Africa:

- The enormous negative consequences of invasive alien plant species in South Africa have provided a strong incentive for investment and innovation in WBC. More than half of the projects listed in Table 2, and nearly all of the current projects, are uniquely South African in that the target weeds have never been considered for WBC elsewhere.

- From the late 1960s, the Department of Agriculture, which had always been the main agency responsible for WBC, developed a team at the Plant Protection Research Institute (PPRI) to increase research activity. An important development at the time was a change in official political strategy which turned the focus of WBC away from the traditional targets of weeds in agricultural and pastoral settings and placed an emphasis on weeds in natural ecosystems and in conservation areas. This change in priority was spurred by the threat of invasive alien trees (Australian Acacia and Hakea species) in the Fynbos Biome. ${ }^{16}$ Projects against these weeds led to innovative expedients to use agents that reduce seed production by feeding on the flowers, buds or seeds, or that induce gall-formation of the reproductive structures, and thus diminish the aggressiveness, but not the usefulness, of the targeted plants. ${ }^{16}$

- Traditionally, the PPRI has concentrated on all the procedures leading up to the release of WBC agents and the monitoring of their fate. From the early 1970s the PPRI encouraged cooperative ventures in WBC with staff at some universities. Although the lines are blurred, university researchers, in collaboration with their PPRI colleagues, have mostly concentrated on long-term projects to evaluate the effects of the WBC agents on the population dynamics of the plants and thereby to determine the levels of success achieved. ${ }^{32-35}$ This pragmatic and collegial division of responsibilities between the PPRI (now in the Agricultural Research Council) and the universities has synergised national WBC endeavours against invasive alien plants. A manifestation of these interactions has been the production of a series of review volumes by the WBC research community in South Africa in $1991^{28}, 1999^{29}$ and in $2011^{30}$, which was preceded by two earlier reviews, one on sweet prickly pear ${ }^{1}$ and the other on jointed cactus ${ }^{31}$. These reviews present a detailed record of all WBC attempts in South Africa over the past century and provide a platform for constructive reflection and planning.
- A key development in WBC research and implementation from 1995 has been the involvement of the Working for Water Programme which has generously supported WBC efforts politically and financially22; it has successfully integrated WBC to supplement its own substantial efforts (involving tens of thousands of people) concentrating on the mechanical and chemical control of invasive alien plants; and has enabled wider international cooperation and especially collaborative ventures into the rest of Africa. ${ }^{22}$

- In 1973, a fledgling WBC research meeting was held at Rhodes University, attended by five people. This meeting turned out to be the forerunner of annual conferences in this country which now attract 150 or more delegates. This escalation in participants is a direct tribute to the involvement of the Working for Water Programme which, besides financial and other support, had the insight to put money into developing capacity in WBC. Of note is their funding of a most successful WBC training programme at Rhodes University, which especially includes people from population groups who until 1994 had had little involvement in these sorts of activities. At the 2013 WBC conference, the majority of the attendees were persons from previously disenfranchised groups and both genders were about equally represented. A remarkably exciting and productive transformation has been achieved in a relatively short time.

- $\quad$ WBC research efforts in South Africa have enjoyed increasing political and public credibility, at least in part because of the involvement of personnel from the South African Council for Scientific and Industrial Research who have shown that WBC is highly cost effective and that it constitutes an essential supplement to other management practices that are aimed at the suppression of invasive alien plants in this country. ${ }^{36,37}$

- In 1996, South Africa hosted the IX International Symposium on Biological Control of Weeds and will host the 14th in this series of meetings in 2014 as part of our WBC centenary celebrations. In spite of a strong emphasis on research results from WBC projects on plants that are not problematic anywhere else in the world, South African publications in WBC have garnered several thousand citations. While this may be comparatively modest, it is clearly an encouraging measure of international recognition and the stage is set for an increase in productivity and success in the field of WBC in this country.

- Lastly, but by no means least, since the 1980s, the practice of WBC, both internationally and in South Africa, has suffered from an escalation in exaggeratedly risk-averse attitudes and restrictive political structures and processes for gaining formal approval for the release of newly tested WBC agents. ${ }^{24,26}$ This situation has slowed and almost stopped WBC progress in South Africa, causing delays that have cost millions while agents are held in quarantine. ${ }^{38}$ Fortunately, in this centenary year, the Directorate of Plant Health of the Department of Agriculture, Fisheries and Forestry, and the Department of Environmental Affairs assisted by the South African National Biodiversity Institute, has re-activated a peer-review process for assessing applications for the release of WBC agents in South Africa. Through this initiative, a protracted stalemate seems to have been broken and the positive significance of this development to our WBC efforts cannot be overstated.

\section{Acknowledgements}

We gratefully acknowledge the support and financial assistance of the University of Cape Town, and of the Working for Water Programme of the Department of Environmental Affairs. Dr B. van Wilgen of the CSIR suggested that we compile this account. Dr van Wilgen and Prof. M.P. Hill, of Rhodes University, kindly provided constructive comments on earlier drafts of this paper. Ms H. Klein of the PPRI also read the manuscript and assisted us in many ways and we are grateful to her for that: in particular she confirmed the coincidence of the first release of a biological control agent against weeds in South Africa, in September $1913^{7}$, with the publication of this commemorative account almost exactly 100 years later. 


\section{References}

1. Annecke DP, Moran VC. Critical reviews of biological pest control in South Africa 2: The prickly pear, Opuntia ficus-indica (L.) Miller. J Entomol Soc S Afr. 1978;41:161-188.

2. Van Sittert L. Our irrepressible fellow colonists: The biological invasion of prickly pear (Opuntia ficus-indica) in the Eastern Cape Colony c. 1870-1910. In: Dovers RW, Edgecombe R, Guest B, editors. South Africa's environmental history: Cases and comparisons. Cape Town: David Philip; 2002. p. 139-159.

3. Burrows EH. The Leyden tradition in South African medicine. S Afr Med J. 1956;30:257-258.

4. Vosloo JA. Report of the Select Committee on prickly pear. Cape of Good Hope. Cape Town: Printed by order of the House of Assembly; 1906. A8-06.

5. Pettey FW. The biological control of prickly pears in South Africa. Sci Bull Dep Agr For Un S Afr. 1948;271:1-163.

6. Zimmermann HG, Moran VC, Hoffmann JH. Invasive cactus species (Cactaceae). In: Muniappan R, Reddy GVP, Raman A, editors. Biological control of tropical weeds using arthropods. Cambridge, UK: Cambridge University Press; 2009. p. 108-129. http://dx.doi.org/10.1017/CB09780 511576348.007

7. Lounsbury CP. Plant killing insects: The Indian cochineal. Agr J S Afr. 1915;1:537-543.

8. Perkins RCL, Swezey $\mathrm{OH}$. The introduction into Hawaii of insects that attack lantana. Hawaiian Sugar Planters' Assoc Expt Sta Entomol Ser Bull. 1924;16:1-83.

9. Dodd AP. The biological control campaign against prickly pear. Brisbane: Commonwealth Prickly Pear Board Bulletin, Government Printer; 1940.

10. Mann J. Cacti naturalized in Australia and their control. Brisbane: Department of Lands; 1970.

11. Richardson DM, Rejmánek M. Trees and shrubs as invasive alien species - a global review. Divers Distrib. 2011;17:788-809. http://dx.doi.org/10.1111/ j.1472-4642.2011.00782.x

12. Shaughnessy GL. Historical ecology of alien woody plants in the vicinity of Cape Town, South Africa [PhD thesis]. Cape Town: University of Cape Town; 1980.

13. Richardson DM, Van Wilgen BW. Invasive alien plants in South Africa: How well do we understand the ecological impacts? S Afr J Sci. 2004;100:45-52.

14. Van Wilgen BW, Reyers B, Le Maitre DC, Richardson DM, Schonegevel L. A biome-scale assessment of the impact of invasive alien plants on ecosystem services in South Africa. J Environ Manage. 2008;89:336-349. http://dx.doi. org/10.1016/j.jenvman.2007.06.015

15. Nel JL, Richardson DM, Rouget M, Mgidi TN, Mdzeke N, Le Maitre DC, et al. A proposed classification of invasive alien plant species in South Africa: Towards prioritizing species and areas for management action. S Afr J Sci. 2004;100:53-64.

16. Moran VC, Hoffmann JH. Conservation of the fynbos biome in the Cape Floral Region: The role of biological control in the management of invasive alien trees. BioControl. 2012;57:139-149. http://dx.doi.org/10.1007/s10526-0119403-5

17. Görgens AHM, Van Wilgen BW. Invasive alien plants and water resources in South Africa: Current understanding, predictive ability and research challenges. S Afr J Sci. 2004;100:27-33.

18. Henderson L. Alien weeds and invasive plants. Plant Protection Research Institute Handbook No. 12. Pretoria: Agricultural Research Council; 2001.

19. Kotzé I, Beukes H, Van den Berg E, Newby T. National invasive alien plant survey. Report No. GW/A/2010/21. Pretoria: Agricultural Research Council Institute for Soil, Climate and Water; 2010. p. 1-45.

20. Coetzee JA, Bownes A, Martin GD. Prospects for the biological control of submerged macrophytes in South Africa. Afr Entomol. 2011;19:469-487. http://dx.doi.org/10.4001/003.019.0203
21. Olckers T. Targeting emerging weeds for biological control in South Africa: The benefits of halting the spread of alien plants at an early stage of their invasion. S Afr J Sci. 2004;100:64-68.

22. Zimmermann HG, Moran VC, Hoffmann JH. Biological control in the management of invasive alien plants in South Africa, and the role of the Working for Water Programme. S Afr J Sci. 2004;100:34-40.

23. Van Wilgen BW, Forsyth GG, Le Maitre DC, Wannenburgh A, Kotzé I, Van den Berg $L$, et al. An assessment of the effectiveness of a large, nationalscale invasive alien plant control strategy in South Africa. Biol Conserv. 2012;148:28-38.

24. Van Wilgen BW, Moran VC, Hoffmann JH. Some perspectives on the risks and benefits of biological control of invasive alien plants in the management of natural ecosystems. Environ Manage. 2013;52(3):531-540. http://dx.doi. org/10.1007/s00267-013-0099-4

25. Bernays EA, Chapman RF. Host-plant selection by phytophagous insects. New York: Chapman and Hall; 1994.

26. Moran VC, Hoffmann JH, Zimmermann HG. Biological control of invasive alien plants in South Africa: Necessity, circumspection, and success. Front Ecol Environ. 2005;3:71-77. http://dx.doi.org/10.1890/1540-9295 (2005)003[0071:BCOIAP]2.0.C0;2

27. Klein $\mathrm{H}$. A catalogue of the insects, mites and pathogens that have been used or rejected, or are under consideration, for the biological control of invasive alien plants in South Africa. Afr Entomol. 2011;19:515-549. http://dx.doi. org/10.4001/003.019.0214

28. Hoffmann JH, editor. Biological control of weeds in South Africa. Agr Ecosyst Environ. Special issue. 1991;37:1-255.

29. Olckers T, Hill MP, editors. Biological control of weeds in South Africa (19901998). Afr Entomol Mem. 1;1999:1-182.

30. Moran VC, Hoffmann JH, Hill MP, editors. Biological control of invasive alien plants in South Africa (1999-2010). Afr Entomol. 2011;19:177-549. http:// dx.doi.org/10.4001/003.019.0218

31. Moran VC, Annecke DP. Critical reviews of biological pest control in South Africa 3: The jointed cactus, Opuntia aurantiaca Lindley. J Entomol Soc S Afr. 1979;42:299-329.

32. Moran VC, Zimmermann, HG. Biological control of jointed cactus, Opuntia aurantiaca (Cactaceae), in South Africa. Agric Ecosyst Environ. 1991;37:527. http://dx.doi.org/10.1016/0167-8809(91)90136-L

33. Hoffmann JH, Moran VC. The population dynamics of an introduced tree, Sesbania punicea, in South Africa, in response to long term damage caused by different combinations of three species of biological control agents. Oecologia. 1998;114:343-348. http://dx.doi.org/10.1007/s004420050456

34. Wood AR, Morris MJ. Impact of the gall-forming rust fungus Uromycladium tepperianum on the invasive tree Acacia saligna in South Africa: 15 years of monitoring. Biol Control. 2007;41:68-75. http://dx.doi.org/10.1016/j. biocontrol.2006.12.018

35. Paterson ID, Hoffmann JH, Klein H, Mathenge CW, Neser, S, Zimmermann HG. Biological control of Cactaceae in South Africa. Afr Entomol. 2011;19:230 246. http://dx.doi.org/10.4001/003.019.0221

36. Van Wilgen BW, De Lange WJ. The costs and benefits of biological control of invasive alien plants in South Africa. Afr Entomol. 2011;19:504-514. http:// dx.doi.org/10.4001/003.019.0228

37. De Lange WJ, Van Wilgen BW. An economic assessment of the contribution of biological control to the management of invasive alien plants and to the protection of ecosystem services in South Africa. Biol Invasions. 2010;12:4113-4124. http://dx.doi.org/10.1007/s10530-010-9811-y

38. Klein H, Hill MP, Zachariades C, Zimmermann HG. Regulation and risk assessment for importations and releases of biological control agents against invasive alien plants in South Africa. Afr Entomol. 2011;19:488-497. http:// dx.doi.org/10.4001/003.019.0215 